\title{
Kitab Futuh el-Sham (Pseudo) Muhammada ibn Umar al-Waqidi'ego jako źródło do studium bitwy nad rzeką Jarmuk (636)
}

Muhammad ibn Umar al-Waqidi stworzył interesujące dzieło z punktu widzenia ideologii wojny. Sam al-Waqidi swe relatywnie długie życie zakończył w Bagdadzie, gdzie przebywał od 796 roku. Jako wysokiej rangi urzędnik kalifa stał blisko Haruna ar-Raszyda oraz jego synów i bezpośrednich następców: al-Amina i al-Mamuna ${ }^{2}$. Jest to okres największej świetności kalifatu Abbasydów. Al-Waqidi pisał zatem swe dzieła w aurze swoistej euforii kulturalno-religijnej islamu. Ten sam duch znamionuje dzieło al-Waqidi'ego. Patrzy on bowiem z perspektywy głębokiej egzaltacji religijnej na wcześniejsze dzieje kalifatu, a w szczególności na początki jego terytorialnej ekspansji. Pod tym kątem więc analizuje również opisaną tam bitwę nad Jarmuk, czyli najważniejszą bitwę w dziejach wczesnego kalifatu, która na wiele wieków przesądziła o losach wschodniej części basenu Morza Śródziemnego. Stworzyła też fundamenty dla podboju Afryki Północnej i Półwyspu Iberyjskiego.

1 Mgr Andrii Matvieiev, doktorant w Katedrze Historii Starożytnej, Bizantyńskiej i Średniowiecznej w Instytucie Historii na Wydziale Humanistycznym Katolickiego Uniwersytetu Lubelskiego Jana Pawła II; e-mail: andriimatvieiev@gmail.com; ORCID: 0000-0002-7202-3215.

2 Por. F. Sezgin, Geschichte des arabischen Schrifttums, t. 1, Veröffentlichungen des Instituts für Geschichte der Arabisch-Islamischen Wissenschaften 10, Leiden 1967, s. 294-297; F. Rosenthal, A History of Muslim Historiography, Leiden 1968, s. 186-193; A.A. Duri, The Rise of Historical Writing among the Arabs, ed. I.I. Conrad, Princeton 1983, s. 37-40; The Encyclopaedia of Islam, t. 11, Leiden 2002, s. 101. 


\section{Kwestia autentyczności Futuh el-Sham}

$\mathrm{Kitab}^{3}$ Futuh el-Sham był i nadal jest uważany za dzieło kontrowersyjne. Złożyło się na to kilka powodów. Niektórzy bowiem uczeni muzułmańscy, w tym współcześni al-Waqidi'emu, nie szczędzili mu słów krytyki. Przykładem może być Ali ibn Sinan al-Nasai ${ }^{4}$. Z drugiej strony al-Waqidi miał swoich zwolenników. Do takich należy al-Darawardi, który uważał al-Waqidi'ego za ważnego świadka wczesnomuzułmańskiej tradycji ${ }^{5}$. Wśród współczesnych historyków źródło to jest także oceniane dość ambiwalentnie z punktu widzenia wartości przekazanych danych. Znacznie wyżej ceni się kitaby al-Baladuri'ego i at-Tabari'ego.

Z kolei historycy, którzy zajmują się epoką wczesnoislamską, tacy jak np. Michael Cook ${ }^{6}$, Patricia Crone ${ }^{7}$, starają się wykazać, że informacje, które są zawarte w dziełach al-Waqidi'ego, nie bazują na powszechnie przyjmowanej tradycji historycznej i powinno się do nich podchodzić z pewną rezerwą . W podobnym tonie wypowiada się również Rizwi S. Faizer. Opinię diametralnie przeciwną natomiast prezentuje Michael Lecker ${ }^{10}$. Autor ten uważa, że problem tkwi raczej w tym, że al-Waqidi czerpie swe dane $z$ nieco innego nurtu tradycji niż inni autorzy wczesnoislamscy. Zdaniem M. Leckera tradycja ta powstała już w VII wieku i w niektórych przypadkach jest sprzeczna z powszechnie przyjmowaną linią przekazu ${ }^{11}$. Al-Waqidi nie tworzył więc zdaniem tego badacza czegoś nowego, ale wiernie zapisał pewien wariant tradycji.

Istnieje także hipoteza, dziś przyjmowana przez pewną grupę badaczy, że Futuh el-Sham, czyli Księga podboju Syrii jest utworem znaczne późniejszym, a powołanie się na autorstwo al-Waqidi'ego ma tylko wzmocnić jego wiarygodność w oczach czytelnika. Zgodnie $\mathrm{z}$ tą tezą utwór ten w formie swoistego romansu historycznego powstał w okresie wypraw krzyżo-

\footnotetext{
Kitab oznacza w języku arabskim księgę.

Ibn Hajr al-' Asqalani, Tahdhib al-Tahdhib, t. 9, Hyderabad 1967, s. 366.

Al-Dhahbi, Mizan al-I'tidal fi Naqd al-Rijal, t. 3, Hyderabad 1953, s. 110-111.

M. Cook, Muhammad, New York 1983, s. 63-64.

P. Crone, Meccan Trade and the Rise of Islam, Princeton 1987, s. 223-224.

Por. Crone, Meccan Trade and the Rise of Islam, s. 223.

9 R.S. Faizer, The Issue of Authenticity Regarding the Traditions of al-Waqidi as established in his Kitab al-Maghazi, ,Journal of Near Eastern Studies” 58/2 (1999) s. 97.

10 M. Lecker, The Death of the Prophet Muhammad's Father: Did Wāqidì Invent Some of the Evidence?, "Zeitschrift der Deutschen Morgenländischen Gesellschaft” 145 (1995) s. 9-27.
}

11 Por. Lecker, The Death of the Prophet Muhammad's Father, s. 9-27. 
wych i miał na celu pobudzić muzułmanów do walki z chrześcijanami ${ }^{12}$. $\mathrm{Z}$ tą tezą starał się polemizować już William Nassau Lees, autor angielskiego przekładu tego dzieła ${ }^{13}$. Jednak biorąc pod uwagę argumenty przeciwników autentyczności tego pisma, należy $\mathrm{z}$ dużą rezerwą traktować tezę, która to unikalne źródło przypisuje bez reszty al-Waqidi'emu. Można przyjąć, że genetycznie daje się je powiązać z jego imieniem, jednak traktat ten posiada również późniejsze warstwy redakcyjne, które nie pochodzą już od al-Waqidi'ego. Jest to zatem przypadek tzw. redakcji narastającej. Wersja ostateczna tej pracy mogła powstać nawet w okresie wypraw krzyżowych i być formą protreptikonu, który miał podtrzymać w muzułmanach ducha walki. Stąd z jednej strony należy traktować Futuh el-Sham krytycznie i w ścisłym powiązaniu z innymi źródłami odnoszącymi się do zagadnień podboju Syrii w VII wieku, z drugiej zaś Księga podboju Syrii zasługuje na swego rodzaju „specjalne traktowania”, właśnie dlatego, że jest dziełem, które odbiega od powszechnie przyjmowanej tradycji historycznej ${ }^{14}$.

$\mathrm{Na}$ potrzeby niniejszego artykułu wykorzystano rosyjski przekład Futuh el-Sham pióra A. Abdullacha. Przekład polski natomiast pochodzi od niżej podpisanego. Podobnie będzie w przypadku odwoływania się do innych źródeł arabskich: podstawą tych odwołań będzie zwykle rosyjski przekład tłumaczony na polski przez autora artykułu.

\section{Okoliczności ataku na Syrię}

W 636 roku cesarz Herakliusz uświadomił sobie skalę niebezpieczeństwa, jakim było powstające teokratyczne państwo Arabów. Zaczął więc gromadzić armię, która miała stawić czoła wojskom muzułmańskim w Syro-Palestynie w decydującej, jak się później okazało, bitwie nad rzeką Jarmuk ${ }^{15}$. Początkowo kalif 'Umar ibn al-Khațtab unikał walki, ponieważ był świadom znacznej przewagi liczebnej wojsk cesarskich. $\mathrm{W}$ pewnym momencie wycofał się nawet z Syrii. Jednak wkrótce zmie-

12 Por. E. Belaev, Sovetskaja istoricheskaja ehnciklopedija, t. 2, red. E. Zhukov, Moskva 1962, s. 933.

13 (Pseudo-)al-Waqidi, The Conquest of Syria commonly ascribed to Muhammad al-Wāqid̄̄, t. 1, ed. W. Nassau Lees, Calcutta 1854, s. xii-xiv.

14 Autor uważa, że źródło zostało napisane nie przez al-Waqidi’ego, lecz prawdopodobnie przez jego ucznia i wskazuje na to w tytule artykułu.

15 W. Treagold, Bizancjum i jego armia 284-1081, Wodzisław Śląski 2011, s. 36; S. Runciman, Dzieje wypraw krzyżowych, t. 1, tł. M. Grabska-Ryńska, Warszawa 1987, s. 28. 
nił zdanie i postanowił zmierzyć się z Bizantyńczykami w dolinie wpomnianej wyżej rzeki ${ }^{16}$. Reputacja Herakliusza jako wybitnego dowódcy mocno niepokoiła muzułmanów. Herakliusz jednak nie ustrzegł się kilku poważnych błędów taktycznych oraz pomyłek w zakresie obsady stanowisk dowódczych ${ }^{17}$. Cesarz zdawał się nie doceniać potencjału islamskiej armii i najprawdopodobniej ten właśnie błąd przesądził o losach zmagań z siłami kalifa ${ }^{18}$.

Z własnej perspektywy patrzą na klęskę chrześcijan autorzy arabscy. W Futuh el-Sham przedstawiono pierwszą reakcję Herakliusza na wieść o wtargnięciu muzułmanów do Syrii. Według niej cesarz miał wysłać dwie armie. Jedną do Cezarei, aby wzmocnić obronę wybrzeża, szczególnie zaś Akry i Tyru. Druga natomiast została wysłana do Jerozolimy. Największą wartość bojową w wojskach cesarskich reprezentowały siły króla Armenii - Bannesa ${ }^{19}$. Tekst arabski niemal drobiazgowo opisuje scenę spotkania Armeńczyka z Herakliuszem:

Kiedy Bannes przybył na spotkanie z Herakliuszem, zsiadł z konia [...], okazując w ten sposób Herakliuszowi szacunek. Z kolei Herakliusz powiedział im na powitanie: „O naśladowcy Chrystusa, o synowie Wody Świętej ${ }^{20}$, ja przecież już niejednokrotnie przestrzegałem was przed Arabami, ale nikt spośród was nie wziął sobie moich uwag do serca. Przysięgam na Chrystusa! Przysięgam na Prawdziwe Pismo Święte! Przysięgam na Komunię Ś więtą! Ci Arabowie będą rządzić i tą ziemią, która znajduje się pod moim tronem! [...]. Arabowie zebrali bowiem takie wojsko, któremu nie przeciwstawi się nikt spośród żyjących władców tego świata".

Autor arabski wkłada więc w usta Herakliusza prorocze słowa, które mają ukazywać cesarza jako swego rodzaju natchnionego męża Bożego. Jednak jest to tylko prolog, poprzedzający istotę wywodu Herakliusza, która brzmi następująco:

16 Por. T. Gregory, Historia Bizancjum, tł. J. Hunia, Kraków 2008, s. 167.

17 Por. D. Nicolle, Yarmuk AD 636. The Muslim Conquest of Syria, Peterborough 2006, s. 17.

18 Por. Nicolle, Yarmuk AD 636, s. 17; W. Treagold, A History of the Byzantine State and Society, Stanford 1997, s. 302-303; S. McAllister, The sword and shield of God: Byzantine strategy and tactics under Heraclius during the last Persian war and first Arab war, Stillwater 2005, s. 37-38.

19 Tak źródło arabskie nazywa Vahana, głównodowodzącego wojska bizantyńskiego.

20 Ochrzczeni, czyli chrześcijanie. 
Skruszcie wasze serca przed Chrystusem i pokutujcie za grzechy. Bądźcie cierpliwi w walce i nigdy nie walczcie jeden przeciw drugiemu. Trzymajcie się z daleka od pychy i zazdrości, ponieważ jeżeli te dwa grzechy spadają na naród, wówczas on staje się bezradny wobec swoich wrogów.

To wyakcentowanie etyczno-moralnych skaz na sumieniach chrześcijan stanowi niejako uzasadnienie późniejszej klęski. Dla autora arabskiego, piszącego swoje vaticinium ex eventu z dużej perspektywy czasowej, to zdrada cnót religijnych zadecydowała o przegranej. W dalszej zaś części tego opisu pojawia się charakterystyka wojowników islamskich, która również została włożona w usta Herakliusza: „Są najsłabszymi wśród stworzeń Bożych. Ich ciała są nagie, ich żołądki są puste. Oni nie mają ani sił, ani uzbrojenia, a mimo to oni właśnie pokonali was przy Busrze ${ }^{21}$, Ajnadaynie $^{22}$, pod Damaszkiem i pod Himsem ${ }^{23}$ ". Siła słabości i słabość siły - tak można najkrócej podsumować tenor tego bardzo sugestywnego passusu. Wreszcie przychodzi czas na wypowiedź chrześcijańskiego kapłana, która nie pozostawia cienia wątpliwości co do tego, dlaczego islam kontynuuje swój zwycięski pochód:

Na te słowa wszyscy zamilkli, a jeden stary i wykształcony kapłan powstał i rzekł: „O cesarzu, czy wiesz dlaczego Arabowie odnoszą nad nami zwycięstwa?”. Herakliusz odparł: „Przysięgam na Chrystusa, nie wiem”. Kapłan zaś odrzekł: „Cesarzu, dzieje się tak dlatego, że nasz naród zniekształcił naszą świętą religię i wniósł do niej liczne herezje. Oni nie dotrzymują postów, nie modlą się, zajmują się lichwą i cudzołóstwem. Tymczasem Arabowie są pokorni wobec swojego Boga i trzymują się przepisów swojej religii. Oni

21 Kronikarzowi chodzi o miasto Basra, które zostało założone przez kalifa Omara w 636 roku jako obóz wojskowy. Znajdowało się w odległości $15 \mathrm{~km}$ na południu od współczesnego miasta o tej samej nazwie.

$22 \mathrm{~W}$ niektórych starych publikacjach z XIX wieku miejscowość ta nosi nazwę Aijnadin w Iturei. Bitwa pod Aijnadin/Ajnadayn to pierwsza poważna walka pomiędzy wojskami kalifatu pod dowództwem Khālida ibn al-Walīda a armią cesarstwa bizantyjskiego. Bitwa zakończyła się 30 lipca 633 roku zwycięstwem Arabów. Por. C. Oman, Thestory of the Byzantine Empire, New York 1892, s. 163; O. Bolshakov Rozhdenije i razvitije islama i musulmanskoj imperiji (VII-VIII ww.), Sankt-Petersburg 2016, s. 223.

23 W lutym 635 roku arabscy przywódcy Khalid ibn al-Walid i Abu 'Ubaydah pokonali wojsko Bizantyńczyków na równinie Marj as-Suffar. Po tym zwycięstwie, 12 marca 635 roku armia kalifa obległa Damaszek. Na pomoc walczącym tam wojskom bizantyńskim wysłano wówczas z Himsu, czyli Emesy, posiłki. Zostały one jednak doszczętnie rozbite 10 sierpnia 635 roku w bitwie pod Beit Lichya. 
modlą się po nocach i poszczą w ciągu dnia. Oni nigdy nie zapominają o swoim Bogu i posyłają pozdrowienia swojemu prorokowi. Wśród nich nie ma miejsca na gnębienie współbrata w wierze. Oni wiedzą, że ziemskie życie jest tylko tymczasowe, a przyszłe życie - wieczne". Herakliusz odrzekł: „Przysięgam na Chrystusa! Powiedziałeś prawdę"24.

Padają słowa, które są niewątpliwie owocem głębokich religijnych przemyśleń, niewolnych od silnie moralizatorskich tendencji. To pochwała istoty islamu - bezgraniczne zaufanie Najwyższemu. Kontrast pomiędzy postawą chrześcijan a muzułmanów gra w tym topicznych zarysie przeciwieństw między wyznawcami obu religii decydującą rolę. Jest to kontrast łatwo uchwytny, a zatem przeznaczony dla każdego czytelnika. On też de facto zamyka ów etyczno-moralny prolog. Jego domknięciem jest konkluzja wypowiedziana przez Herakliusza: „W tej sytuacji postanowiłem odesłać moje wojsko, sam zaś zabiorę moją rodzinę i bogactwa, i udam się do Konstantynopola, gdzie będę bezpieczny". Jest to moment całkowitej rezygnacji. Cesarz uznaje klęskę moralną swego imperium. Klęska militarna staje się w tej perspektywie niemal koniecznością, którą dobrze rozumie Herakliusz - mąż Boży w koncepcji islamskiego autora. Jednak nieuchronności tej katastrofy nie rozumieją jego poddani - oficerowie sztabowi:

Rzymianie odpowiedzieli: „Cesarzu, nie czyń tego. Nie oddawaj na pośmiewisko i pogwałcenie wiary Chrystusowej, ponieważ On zapyta Cię o to w Dzień Sądu Ostatecznego. Tutaj mamy tak liczne wojska, jakich nie miał jeszcze żaden władca. Wystąpmy zatem przeciw Arabom i bądźmy wytrwali w walce z nimi. Może Chrystus pomoże nam w tej wojnie przeciwko nim"25.

Jednak oni odwołują się już nie do Boga, lecz do Chrystusa. Muzułmański autor, czytelnik Koranu, zna dobrze miejsce Chrystusa w hierarchii tej księgi. Nie przypadkiem więc zmienia orędownika chrześcijan. W konsekwencji klęskę nad Jarmuk nie poniesie Bóg, który jest jeden i jedyny, lecz Chrystus, którego nierozumiejący istoty zbliżającej się klęski wojskowi przyzywają na pomoc. Jednak Chrystus nie może pokonać Boga. Sedno tego wprowadzenia jest bez reszty oparte na doktrynie koranicznej i do wyznawców Koranu jest adresowane. Tekst ten niekoniecznie musi być dziełem jednego autora. Jego głębię dobrze zdaje się

\footnotetext{
24 Al-Waqidi, Futuh el-Sham III 1-2, tt. A. Abdullach, s. 218.

25 Al-Waqidi, Futuh el-Sham III 1-2, tt. A. Abdullach, s. 218-219.
} 
tłumaczyć wspomniana wyżej teza o narastającej redakcji Futuh el-Sham. To owoc przemyśleń wielu pokoleń muzułmańskich intelektualistów na temat epokowego znaczenia starcia nad Jarmukiem. W ich interpretacji było to starcie „niewiernych uczniów Chrystusa” z ,prawowiernymi wyznawcami Allaha (Boga par excellence)". Sama bitwa schodzi na drugi plan. Prawdziwym źródłem klęski były bowiem nie błędy w sztuce wojennej, lecz fakt, że chrześcijanie przez zdradę swoich własnych ideałów religijnych sami skazali się na wojenną katastrofę.

\section{Dowódcy armii bizantyńskiej i jej liczebność}

Al-Waqidi podał wiele informacji na temat przygotowań Bizantyńczyków do bitwy. Scharakteryzował również dowódców wojskowych, traktując własnych jak bohaterów narodowych, dzięki którym podbito Syrię, a bizantyńskich jako ludzi de facto niezdolnych do wydawania przemyślanych rozkazów. Futuh el-Sham zawiera także ważny opis tzw. wręczenia pięciu sztandarów bizantyńskim dowódcom:

Herakliusz postanowił wysłać wojska z pięcioma królami ${ }^{26}$ Imperium Rzymskiego na czele. Rozkazał też przynieść sztandar czerwony, haftowany złotem, którego zwieńczeniem był drewniany, zdobiony drogocennymi kamieniami krzyż. Ten to sztandar wręczył królowi Północnej Europy $^{27}$ i ustanowił go wodzem nad wojskiem liczącym 100 tysięcy wojowników pieszych i konnych. Drugi sztandar był biały z wyhaftowanym złotym słońcem w centrum. Na końcu drzewca znajdował krzyż wykonany ze szmaragdu. Cesarz wręczył go z kolei „władcy” Amorium² ${ }^{28}$. On został postawiony na czele 100 tysięcy kawalerzystów pochodzących $\mathrm{z}$ różnych części Bizancjum. Trzeci sztandar wykonano z tkaniny kolorowej. Widniał zaś na nim złoty krzyż. Został wręczony Trajanowi ${ }^{29}$, dowódcy Konstantynopola, który otrzymał pod swoją komendę 100 ty-

26 Tak kitab nazywa wodzów bizantyńskich.

27 Autor ma na myśli najemników wareskich pochodzących ze Skandynawii. Jest jednak mało prawdopodobne, aby faktycznie byli to Skandynawowie. Autorowi mogło chodzić o to, by pokazać, że w wojsku cesarskim były wszystkie narody ekumeny.

28 Miasto frygijskie. Znajdowało się na terenie Azji Mniejszej. W 838 roku zostało złupione przez Arabów.

29 Nie ma o nim więcej informacji poza wspomnieniem kronikarza. 
sięcy Mongołów, Franków ${ }^{30}$ i Kalnów ${ }^{31}$. Czwarty sztandar został wykonany z czarnej tkaniny. Herakliusz wręczył go Teodorowi i postawił go na czele 100 tysięcy Mongołów i Ormian. Piąty zaś sztandar był zdobiony perłami i drogocennymi kamieniami. Jego drzewce było zrobione ze złota, a rubin zdobił jego grot. Herakliusz wręczył go Vahanowi, wodzowi z Armenii, którego bardzo szanował za jego męstwo i chytrość. Do niego zaś cesarz powiedział: „Bannesie, oto mianuję cię głównodowodzącym mego wojska. Twoje słowo i Twój rozkaz będzie ponad słowami innych". Następnie cesarz zwrócił się do pozostałych: „Wasze krzyże będą pod jego krzyżem. On ma nad wami pełnię władzy. Niczego nie czyńcie zatem bez jego zgody. Brońcie waszej religii i sprawiedliwego prawa Bożego. Rozdzielcie się zatem i wyruszajcie czterema różnymi drogami, ponieważ, jeżeli pójdziecie jedną drogą, kraj nie wykarmi tak ogromnego wojska, a ponadto stratujecie wszystkie miejscowości, przez które będziecie przechodzić, i wszystkich, kto tam będzie się znajdował". Potem podarował drogocenne ubranie Jabale ibn al-Aihamowi Ghassani i mianował go dowódcą nad chrześcijańskimi Arabami plemienia Ghassan, Lakhm i Juthâm². Powiedział też: „Wy Arabowie będziecie awangardą, ponieważ do zniszczenia kogoś (tak twardego) trzeba znaleźć podobnego do niego. Tylko żelazo bowiem tnie żelazo". Następnie Herakliusz rozkazał kapłanom pokropić ich wodą święconą, czytać nad nimi Pismo Święte i modlić się za nich ${ }^{33}$.

Tekst ten nie przypadkiem kładzie nacisk na szeroko rozumiany przepych. $Z$ jednej bowiem strony kontrastuje z nim milcząco ubóstwo żołnierzy kalifa, z drugiej zaś przywołuje znany topos literacki odpisujący tzw. zniewieścienie.

Z kolei wymienieni w powyższym tekście dowódcy są dobrze znani historykom bitwy nad Jarmuk. Jednym z nich był brat cesarza, Teodor. Dowodził on wcześniej wojskami bizantyńskimi pod Ajnadayn. Był to weteran wojny bizantyńsko-perskiej. Kroniki muzułmańskie przedstawiają go

30 Prawdopodobnie chodzi tu o posiłki z Europy Zachodniej.

31 O wielonarodowym składzie wojsk bizantyńskich pisze Saifuz Zaman, por. S. Zaman, Yarmouk - The Necessity of Studying the Battle in Early Medieval Military Historiography, ,Journal of Military and Strategic Studies” 16/2 (2015) s. 63.

32 Te plemiona były sojusznikami Bizancjum i wyznawały chrześcijaństwo, najczęściej w wersji monofizyckiej.

33 Al-Waqidi, Futuh el-Sham III 3, tł. A. Abdullach, s. 190-191. Por. Treagold, A History, s. 303. 
jako człowieka agresywnego, lekkomyślnego i buntowniczego. Po przegranej pod Ajnadayn rozgniewany cesarz zarzucał bratu nieroztropność i nieposłuszeństwo, a ostatecznie odesłał go do Konstantynopola ${ }^{34}$. Niestety nad Jarmukiem ów „zły duch” armii bizantyńskiej pojawił się ponownie, walnie przyczyniając się do jej klęski.

Kolejnym cesarskim dowódcą był Vahan ${ }^{35}$. Ten Ormianin z pochodzenia był bardzo dobrze zorientowany w sytuacji na Bliskim Wschodzie. Pełniąc zaś funkcję dowódcy garnizonu Emesy, był drugim rangą oficerem w Syrii po Herakliuszu. Odpowiadał tutaj m.in. za dostarczanie posiłków zbrojnych z Armenii i Konstantynopola. Miał również zmobilizować lojalne wobec cesarstwa plemiona arabskie ${ }^{36}$.

Niketas $^{37}$ natomiast był synem perskiego wodza Szahrbaraza ${ }^{38}$. Niketas był bardzo zdolnym strategiem, a ponadto dobrze znał Syrię - arenę przyszłych walk z Arabami. Jego ojciec był przychylny chrześcijanom $\mathrm{i}$ istnieje wielkie prawdopodobieństwo, że Niketas był chrześcijaninem. Lojalność Niketasa i jego oddziałów wobec cesarza wydaje się dyskusyjna $^{39}$. Można nawet sądzić, że byli oni skłonni do zawarcia porozumienia $\mathrm{z}$ muzułmanami.

Wreszcie Jabal ibn al-Aiham (zm. 645), ostatni szejk Ghassanidów, był prawdopodobnie chrześcijaninem i dobrze znał swoich muzułmańskich wrogów. W czasie poprzednich dwóch dekad Jabal walczył przeciwko wrogom Bizancjum - Sasanidom. Przeżył też porażkę armii cesarskiej nad rzeką Jarmuk, a następnie przyczynił się do ustanowienia tymczasowego pokoju z muzułmańskimi szejkami w Syrii. Ostatecznie jednak popadł w konflikt z kalifem Omarem i opuścił Syrię wraz ze swoimi oddziałami ${ }^{40}$.

34 Por. W. Kaegi, Byzantium and the Early Islamic Conquests, Cambridge 2005, s. 119.

35 Por. Kaegi, Byzantium, s. 119.

36 Niektóre plemiona arabskie, jak już wyżej wspomniano (por. przyp. 30), były sojusznikami cesarstwa. W obrębie wpływów Bizancjum znajdowały się m.in. arabskie plemiona Tanuchidów, Salichidów, Kindydów i Ghassanidów.

37 Syn dowódcy perskiego Szahrbaraza, który walczył przeciw Herakliuszowi w wojnie bizantyńsko-sasanidzkiej. Dowodził oddziałami perskimi, które walczyły nad rzeką Jarmuk.

38 Spahbod, czyli głównodowodzący wojsk perskich za czasów panowania Chosroesa II. W latach 613-614 zdobył Damaszek i Jerozolimę. Potem obalił Ardashira III i został uzurpatorem. Zawarł z Bizancjum pokój honorowy. Został zamordowany 9 VI 630 roku.

39 Por. Kaegi, Byzantium, s. 119.

40 Por. Zaman, Yarmouk, s. 172. 
Cały powyższy opis ma głęboko symboliczny charakter. Oto czterech wodzów ${ }^{41}$, z których każdy prowadzi po 100 tys. wojowników ${ }^{42}$, zostaje oddanych pod komendę piątego, naczelnego dowódcy. Mają iść na pole bitwy czterema różnymi drogami, przybywając na nie niejako z czterech stron świata. Jednak nie im przypadła najważniejsza rola. Zdaniem muzułmańskiego kronikarza najważniejszy jest piąty oddział, złożony ze schrystianizowanych Arabów, którymi dowodzi Jabal, a którego liczebność nie została określona. Ten oddział nie podlegał rozkazom naczelnego wodza. Symboliczne są także opisy sztandarów, zarówno w sferze barw $^{43}$, jak i znajdujących się na nich emblematów ${ }^{44}$. Na podstawie tych liczb można by wnosić, że armia cesarska składała się z około pół miliona zbrojnych.

Jednak w innym miejscu analizowanego dzieła została podana diametralnie różna liczba żołnierzy cesarskich, uczestniczących w bitwie nad Jarmuk. Może to stanowić dowód na narastającą redakcję Futuh el-Sham. Oto rzeczony tekst:

${ }^{41}$ W symbolice arabskiej liczba 4 oznacza cztery pory roku, cztery księgi (Torę, Psalmy Dawidowe, Ewangelię i Koran), cztery żywioły (ogień, wodę, ziemię i powietrzę) oraz cztery cnoty (godność, wiarę w jedynego Boga, skromność i dobre obyczaje). Por. M. Dziekan, Symbolika arabsko-muzutmańska, Warszawa 1997, s. 58.

42 W tym kontekście prawdopodobnie oznacza nieskończoność.

43 W kulturze arabsko-muzułmańskiej kolor biały odpowiada wodzie. Symbolizuje czystość rytualną i dobrą wróżbę. Był też symbolem dynastii Umajjadów (661-750). Kolor biały w sensie ogólniejszym oznacza islam jako taki. Kolor czarny z kolei symbolizuje ziemię. Był też odnoszony do dynastii Abbasydów (750-1258). Jest oznaką ascetów. Utożsamia się z północą i z tym, co złowrogie. Czerwieni wśród żywiołów odpowiada powietrze. Czerwień jest symbolem Alego. Symbolizuje też życie, krew i miłość. Jest także uważany za kolor ochronny. Z kolei kolor niebieski jest symbolem chrześcijan. Zielony natomiast to najbardziej charakterystyczny kolor islamu. Symbolizuje w tej religii raj, mądrość i proroków. Wreszcie kolor żółty odpowiada ogniu i uchodził za znak rozpoznawczy Żydów. Por. Dziekan, Symbolika arabsko-muzutmańska, s. 58; E. Kukhareva, Simvolika cveta w etnicheskoj kartine mira arabov, Moskwa 2019, s. 97-105.

44 Groty sztandarów były zwieńczone krzyżami. Pomimo tego, że krzyż jest symbolem chrześcijaństwa, w islamie zachował on związki ze swoim pierwotnym znaczeniem symbolicznym, tj. oznacza wspólnotę wszystkich stanów bytowych. Jest również symbolem najwyższego Bytu. Por. Dziekan, Symbolika arabsko-muzułmańska, s. 53. Najcenniejszy sztandar należał do Vahān'a i był zdobiony perłami. Perła w islamie ma szczególne znaczenie. Jest symbolem czystości. W Koranie oznacza i symbolizuje to, co najdoskonalsze. Występuje m.in. w opisie raju. Jest symbolem Słowa Bożego. Por. Dziekan, Symbolika arabsko-muzulmańska, s. 81. 
Raszyd ibn Said Himjari przekazał: „Uczestniczyłem w walce nad Jarmukiem od początku do końca. Kiedy przybyły wojska Rzymian, ja wszedłem na pagórek i policzyłem ich sztandary - było ich dwadzieścia. Po tym, jak Bizantyńczycy postawili obóz, Abu 'Ubaydah 'Amir ibn 'Abdillah ibn al-Jaraḥ ${ }^{45}$ wysłał niejakiego Romanusa, aby sprawdził ich liczebność. On zaś zaczął opowiadać: „Słyszałem, jak oni mówili pomiędzy sobą, że ich liczebność stanowi około miliona, ale nie wiem, czy nie mówili tego specjalnie, aby szpiedzy usłyszeli to i przekazali nieprawdziwą wiadomość”. Wtedy Abu 'Ubaydah spytał: „Ile twoim zdaniem ludzi znajduje się pod każdym sztandarem?". Romanus odpowiedział: „Zgodnie z tym, co widziałem, pod każdym sztandarem znajduje się około 50 tysięcy wojowników”. Na to Abu 'Ubaydah rzekł: „Allahu Akbar! Oto otrzymaliśmy radosną wieść o pomocy Allaha”. Abu 'Ubaydah miał też innych szpiegów w wojsku bizantyńskim w czasie, kiedy Herakliusz wysłał swoje wojska przeciw muzułmanom. Kiedy oni spotkali się z Abu 'Ubaydą w mieście Jabiyah ${ }^{46}$, opowiedzieli mu o liczebności wojsk chrześcijańskich. Wódz zaś powiedział: „Nie ma możliwości uniknąć zła i nie ma siły tworzyć dobro, jak tylko z pomocą Allaha, Najwyższego i Wszechmogącego". Spędziwszy całą noc na modlitwie, Abu 'Ubaydah przemówił do ummy ${ }^{47}$ : „O muzułmanie, niech się zmiłuje nad wami Allah. Wiedzcie bowiem, że Allah chce poddać nas wielkiej próbie, aby zobaczyć, jak postąpimy. Moi informatorzy powiedzieli, że wróg Allaha, Herakliusz, otrzymał posiłki od władców wielu krajów pogańskich. Teraz wysłał je przeciw wam dobrze wyposażone i uzbrojone. Wiedzcie jednak, że Allah jest z wami. Porzuceni przez Allaha są nieliczni, a ci, z którymi jest Allah, nie są sami”"48.

Al-Waqidi posługuje się tutaj klasycznym toposem literackim, ukazując bezsilność wrogów w obliczu pomocy udzielonej muzułmanom „,z góry”. Jednak liczba wrogów ulega gwałtownemu wzrostowi: oto nad armią bizantyńską ma powiewać 20 sztandarów, a pod każdym z nich ma być zgromadzonych 50 tys. żołnierzy. Ta ewidentnie przesadzona liczba ma jednak swoje uzasadnienie: Allah nie opuszcza swych wiernych mimo potęgi wroga. Zwycięstwo nad nieprzeliczonymi masami niewiernych zaś pomnoży chwałę Allaha i ukaże światu Jego moc.

45 Bliski towarzysz Mahometa. Dowodził podbojem Syrii.

46 Prawdopodobnie chodzi o miasto, które znajdowało się na Wzgórzach Golan, górzystym regionie na pograniczu obecnych Syrii, Libanu i Izraela. Może też chodzić o Bab al-Jabiyah, jedną z bram Damaszku - „Bramę Wodną”.

47 Wspólnota muzułmańska.

48 Al-Waqidi, Futuh el-Sham III 4, tł. A. Abdullach, s. 191-192. 


\section{Dowódcy armii muzułmańskiej}

W czasie inwazji islamskiej kalifem był Omar ibn al-Khaț̣ab. Był to z jednej strony człowiek inteligentny i obdarzony wielką siłą ducha, a ponadto doświadczony dowódca. $\mathrm{Z}$ drugiej zaś strony miała go cechować skromność. Poprowadził on armię muzułmańską do największych w jej historii zwycięstw. Omar osobiście dowodził podbojami, a przy tym ściśle kontrolował swoich podwładnych, narzucając im z żelazną konsekwencją zarówno swoją wolę, jak i swoją wizję ekspansji kalifatu" ${ }^{49}$. Atak na Syrię wykonały trzy armie, którymi dowodzili: 'Amr ibn al- 'As al-Sahmi ${ }^{50}$, Abu Sufyan ${ }^{51}$ i Shurahbil ibn Hasana ${ }^{52}$. Abu Sufyan odniósł dwa zwycięstwa: w Wadi al-Araba i pod Datinem w lutym 634 roku. W tej ostatniej bitwie zostały pokonane wojska bizantyńskie pod dowództwem patriarchy Sergiusza ${ }^{53}$. To zwycięstwo oręża muzułmańskiego miało ogromne skutki propagandowe, ponieważ przyczyniło się do powstania szkodliwej dla morale cesarskich wojsk i ludności cywilnej ,wieści gminnej”, jakoby pod Datinem zginął sam patriarcha Sergiusz ${ }^{54}$. W 634 roku Omar ibn al-Khattab odniósł szereg kolejnych zwycięstw nad Bizantyńczykami ${ }^{55}$. Największym osiągnięciem kalifa było zdobycie Damaszku. Początkowo cesarz Herakliusz bagatelizował te porażki, ponieważ nie był to pierwszy najazd plemion arabskich na tereny cesarstwa ${ }^{56}$. Do osiągnięć Omara należało m.in. powołanie organizacji, która odpowiadała za żołd żołnierzy zgodnie z tzw. listą dywanową ${ }^{57}$, na którą

49 Por. Nicolle, Yarmuk AD 636, s. 19; D. Danyluk, Pryčyny uspišnyh arabskyh zavojuvan v 30-h rokah VII st. u vizantijskomu napriami: istoriohrafija pytannia, w: Aktualni problem vitčyznianoji ta vsesvitnioji istoriji, vyp. 19, Kharkiv 2016, s. 33.

50 Członek plemienia Kurajszytów. Na początku jeden z największych wrogów Mahometa, potem zaś jego najwierniejszy towarzysz. Słynny dowódca wojskowy. Szczególnie wyróżnił się w bitwie nad Jarmukiem i w walkach o Egipt. Po śmierci kalifa Ali poparł nowo powstały kalifat Umajjadów. Por. D. Sourdel - J. Sourdel, Dictionnaire historique de l'islam, Paris 1996, s. 81; H.A.R. Gibb - J.H. Kramers, Shorter Encyklopaedia of Islam, Leiden 1995, s. 42.

51 Sakhr ibn Harb ibn Umayya ibn 'Abd Shams był bratem Mu 'awiyi ibn Abi Sufyana, przyszłego założyciela dynastii Umajjadów.

52 Al-Basri, Futuh ash-Sham, ed. W.N. Lees, Calcutta 1853-1854, s. 40.

53 Patriarcha Konstantynopola w latach 610-630. Był doradcą cesarza Herakliusza.

Por. R. Sawa, Sergiusz I, Sergios, EK XVIII 45.

54 Doctrina Iacobi nuper baptizati, t1. V. Deroche, Paris 1991, s. 208-209.

55 Por. G. Ostrogskij, Istorija Vizantii, Moskwa 2011, s. 161.

56 Por. Gregory, Historia Bizancjum, s. 167.

57 Dywan - rada na dworze kalifa lub sułtana. 
zostali wpisani wszyscy mężczyźni, zdatni do pełnienia służby wojskowej. Omar był również twórcą muzułmańskiej kawalerii. W tym celu stworzył organizację, która zajmowała się głównie gromadzeniem jak najlepszych koni bojowych $^{58}$.

Wśród plejady dobrych dowódców muzułmańskich tego okresu szczególną estymą cieszył się Khalid ibn al-Walid. Był on początkowo, podobnie jak Omar, przeciwnikiem Mahometa. Uchodził przy tym za człowieka porywczego, nieustraszonego, i pozbawionego skrupułów. Uchodzi dziś za jednego z najzdolniejszych taktyków w historii islamskiej wojskowości. Wśród Arabów nosił przydomek „Sajf Allah” - 'miecz Allaha'59. Gdy przeszedł na stronę proroka, wykazał się wręcz skrajną brutalnością w tępieniu zdrajców wiary w latach $632-633^{60}$, czyli w czasie tzw. wojen Riddah. Był także pierwszym muzułmańskim dowódcą, który nałożył na pokonanych wrogów podatek zwany jizyah ${ }^{61}$, płacony przez innowierców ${ }^{62}$. Poważnym cieniem na jego karierze wojskowej położył się jednak osobisty konflikt z kalifem Omarem, który ostatecznie odwołał Khalida $\mathrm{z}$ funkcji głównodowodzącego wojsk arabskich, mianując na jego miejsce Abu 'Ubaydę 'Amira ibn 'Abdullaha ibn al-Jaraha ${ }^{63}$. Tym niemniej tuż po zdobyciu al-Hiry ${ }^{64}$ Khalid wyruszył lojalnie na pomoc wojskom arabskim pod Damaszkiem. Niedaleko tego miasta pod Marj Rahit pokonał plemię Ghassanidów. Z kolei po połączeniu sił arabskich pokonał na ich czele trzon wojsk bizantyńskich pod Ajnadaynem ${ }^{65}$. Największym triumfem Khalida ibn al-Walida przed wygraną nad Jarmukiem było zdobycie Damaszku we wrześniu 635 roku, po półrocznym oblężeniu ${ }^{66}$.

58 Por. Nicolle, Yarmuk AD 636, s. 20.

59 Por. A. Akram, Rycar pustyni. Khalid ibn al-Walid. Krushenije imperij, SanktPetersburg 2009, s. 43-44; M. Al Hudari, Zhyzneopisanije pravednyh Halifov, Moskva 2009, s. 87-89; Treagold, A History, s. 303-304; Dictionary of Islam, ed. by T.P. Hughes, New-Delhi 1978, s. 268.

60 W jęz. ang. Riddah Wars, czyli wojny z apostazją.

$61 \quad \mathrm{Z}$ jęz. ar. oznacza pogłówne.

62 Por. Nicolle, Yarmuk AD 636, s. 20.

63 Por. O. Bolshakov, Istorija Halifata, t. 2, Moskwa 1989, s. 67.

64 Starożytne, obecnie nieistniejące miasto. Znajdowało się na południe od dzisiejszego miasta al-Kufa w Iraku.

65 Por. Ph. Hitti, Dzieje Arabów, tł. W. Dembski, Warszawa 1969, s. 128.

66 Por. H. Kennedy, Wielkie arabskie podboje. Jak ekspansja islamu zmieniła świat, tł. M. Wilk, Warszawa 2011, s. 75; B. Cecota, Arabskie oblężenia Konstantynopola w VII-VIII wieku. Rzeczywistość i mit, Byzantina Lodziensia 21, Łódź 2015, s. 18. 
Innym ważnym dowódcą sił islamskich był, wspomniany już wyżej, Abu 'Ubaydah, który uchodzi za całkowite przeciwieństwo Khalida ibn al-Walida. Ten gorliwy wyznawca islamu nie posiadał jednak talentów wojskowych. Kalif Omar wysłał go do Syrii z przyczyn politycznych. Abu 'Ubaydah był o wiele bardziej ugodowy niż Khalid ibn al-Walid, czego dowiódł m.in. w trakcie walk w latach 632-633, kiedy to pełnił funkcję naczelnego dowódcy sił muzułmańskich. Abu 'Ubaydah także o wiele łagodniej traktował pokonanych chrześcijan w Syriii ${ }^{67}$.

Z kolei 'Amr ibn al-'As al-Sahmi był zarówno wybitnym dowódcą wojskowym, jak i politykiem. To on podbił południowo-zachodnią część Palestyny. Jednak jego największym sukcesem militarnym było opanowanie „,bizantyńskiego" Egiptu ${ }^{68}$. Kitab wprost nie podaje ścisłej charakterystyki wodzów, ale lektura tego pisma pozwala na naszkicowanie ich portretów na podstawie przytoczonych wypowiedzi i czynów.

\section{Przebieg bitwy}

Jeśli chodzi bitwę nad Jarmukiem, to al-Waqidi twierdzi, że to właśnie Khalid ibn al-Walid wybrał miejsce spotkania obu wrogich armii. Dziejopis muzułmański podkreśla przy tym zgodną współpracę islamskich dowódców, mimo że dzieliły ich, jak wiadomo, ogromne różnice poglądów oraz charakterów ${ }^{69}$. Na bazie obrazu tej konstruktywnej zgody al-Waqidi zbudował bezpośrednie wprowadzenie do opisu bitwy. W nadchodzącym bowiem starciu wola wzajemnego porozumienia się dowódców będzie stanowić podstawę dobrej koordynacji działań, a ta utoruje muzułmanom drogę do zwycięstwa. Jest to kolejny przykład budowania fabuły literackiej na prostej zasadzie antytetycznej: zgoda panuje wśród wyznawców islamu, niezgoda dzieli chrześcijan. Wiadomo zaś, że wojska bizantyńskie, którymi dowodził Vahan, maszerowały kolumną rozciągniętą na trzynaście kilometrów, a pomiędzy poszczególnymi oddziałami były znaczne luki ${ }^{70}$.

${ }^{67}$ Por. Nicolle, Yarmuk AD 636, s. 20-21; al Hudari, Zhyzneopisanije pravednyh Halifov, s. 87-89.

68 Por. Nicolle, Yarmuk AD 636, s. 20-21.

69 Al-Waqidi, Futuh el-Sham III 7, tł. A. Abdullach, s. 194.

70 Por. Nicolle, Yarmuk AD 636, s. 20-21. 
Po przybyciu na pole bitwy Bizantyńczycy uformowali swe oddziały do walki. Prawym skrzydłem dowodził Gargis ${ }^{71}$, który wyposażył ciężką piechotę w wielkie tarcze, nadające się do formowania szyku zwanego „ścianą tarcz" ${ }^{2}$. Niedaleko doliny Jarmuk, piechota ta odgrywała rolę „,kotwicy” stabilizującej resztę linii cesarskich. Z kolei sam Vahan sprawował dowództwo nad centrum, które składało się z żołnierzy ormiańskich. Arabskie oddziały sojusznicze pod dowództwem wspominanego już tutaj wielokrotnie Jabali zostały natomiast przeznaczone do zadań wspierająco-pomocniczych na lewych skrzydle. Oddziały te składały się z lekkiej kawalerii i niewielkiej ilości piechoty, której towarzyszyły wielbłądy ${ }^{73}$. Oddziały te we wstępnej fazie bitwy pełniły funkcję zwiadowców. W drugiej natomiast fazie starcia stanowiły one osłonę lewego skrzydła wojsk bizantyńskich. Reszta sił Jabali miała zabezpieczać most nad Wadi Ruqqad, który znajdował się około $3 \mathrm{~km}$ za pozycjami bizantyńskimi ${ }^{74}$. Zgodnie z późniejszymi źródłami ormiańskimi armia bizantyńska miała być podzielona na 20 oddziałów. Vahan zaś i jego „sztab” mieli znajdować się na niewysokim wzgórzu za prawym skrzydłem. Najprawdopodobniej był to pagórek leżący na południowy wschód od dzisiejszego Ayn Dhakar ${ }^{75}$. Jeżeli założyć, że droga rzymska z mostu Ruqqad do Tsil biegła przez centrum „frontu” bizantyńskiego, to rzeczone wzgórze znajdowało się nieco po prawej stronie szyku Bizantyńczyków. Jemu podlegały także oddziały broniące skrzyżowania dróg, które dziś nosi nazwę Rujm al-Mushabbah, co z języka arabskiego thumaczy się jako "mogiły tych, którzy rozpalili płomień wojny ${ }^{96}$. Prawe skrzydło składało się z elitarnych formacji piechoty bizantyńskiej. Za nimi zaś rozciągała się wielka otwarta przestrzeń, pokryta kamieniami i małymi kopcami ze szkła wulkanicznego. Nie blokowały one jednak wylotu wąwozu Wadi Ruqqad leżącego kilka kilometrów dalej, ale sprawiały, że od południa przeciwnik nie mógł

71 Gargis Ormiański. W. Kaegi nazywa go Gargisem z Armenii. Por. Kaegi, Byzantium, s. 121; Nicolle, Yarmuk AD 636, s. 20-21;

72 Por. Nicolle, Yarmuk AD 636, s. 20-21.

73 Dzięki wielbłądom, na których podczas marszu przewożono zaopatrzenie i rzeczy osobiste, wojsko to było niezależne od dostaw zaopatrzenia i bardzo mobilne. Taka mobilność i brak zależności od dostaw zaopatrzenia dawała Arabom gigantyczną przewagę nad nieprzyjacielem. Por. Akram, Rytsar pustuni, s. 200-201; Bolshakov, Istorija Halifata, t. 2, s. 16-17; Danyluk, Prychyny uspishnyh arabskich zavojuvan, s. 32.

\footnotetext{
74 Por. Nicolle, Yarmuk AD 636, s. 66.

75500 m n.p.m.

76 Por. Nicolle, Yarmuk AD 636, s. 66.
} 
obejść tej naturalnej przeszkody. Na tym obszarze Vahan kazał rozproszyć lewą flankę swego zgrupowania, co z taktycznego punktu widzenia można uznać za posunięcie bardzo ryzykowne. Wódz bizantyński stawiał tu zapewne na przewagę liczebną, która była czterokrotna ${ }^{77}$. Kitab zaś podaje, że obóz bizantyński znajdował się w odległości 3 farsachów, czyli 16,5 kilometrów od obozu arabskiego ${ }^{78}$.

W tym czasie naczelnicy armii islamskiej posiadali już dobrą znajomość możliwości militarnych wroga. Tradycja mówi, że zebrali się na Tell al-Juma, jednym z licznych wzgórz na północ od Tsil, gdzie również skoncentrowano znaczną część sił muzułmańskich, które prawdopodobnie tworzyły prawe skrzydło sił kalifatu ${ }^{79}$. Kitab podaje, że Abu 'Ubaydah po dostaniu się nad Jarmuk rozbił obóz i rozkazał ulokować dzieci i kobiety na wzgórzu obok, a wszystkie zapasy miały pozostawać na tyłach obozu ${ }^{80}$.

Dowodzenie armią Abu 'Ubaydah powierzył Khalidowi ibn al-Walidowi. Ten zaś miał podzielić swoje oddziały na 36 formacji piechoty tworzących cztery zgrupowania. Każde z nich liczyło po dziewięć pieszych regimentów. Z kolei z jazdy sformowano trzy oddziały, którymi dowodzili Qays ibn Hubaurah, Maysara ibn Masruq i Amir ibn Tufayl. Kawalerię tę ustawiono za centrum. Miała ona w przypadku zagrożenia osłaniać piechotę. Wojsko muzułmańskie znajdowało się pomiędzy Saham al-Jawlan i Tell al-Jabiya, w odległości około półtora kilometra od pozycji bizantyńskich ${ }^{81}$. Khalid ibn al-Walīd jako naczelny dowódca koordynował działania armii, która w ramach szyku bitewnego została podzielona na trzy segmenty. Każdy z nich posiadał własnego dowódcę: Abu Sufyan kierował lewym skrzydłem sił kalifatu, Abu 'Ubaydah 'Amir ibn 'Abdullah ibn al-Jarah stał na czele sił centralnych, 'Amr ibn al-'As al-Sahmi zaś dowodził prawym skrzydłem. Łucznicy muzułmańscy, którzy byli jemeńskimi Arabami, rozciągnęli się wzdłuż linii frontu. Oddziały jazdy rezerwowej pozostawały pod bezpośrednią komendą Khalida ibn al-Walida ${ }^{82}$. Nie ustalono do dnia dzisiejszego dokładnego miejsca lokalizacji obozu arabskiego. Ph. Hitti i H. Kennedy podają tylko, że kalif skoncentrował swoje siły w dolinie

\footnotetext{
77 Por. Nicolle, Yarmuk AD 636, s. 66.

78 Al-Waqidi, Futuh el-Sham III 8, tt. A. Abdullach, s. 195.

79 Por. Bolshakov, Istorija Halifata, t. 2, s. 66-68; Nicolle, Yarmuk AD 636, s. 67.

80 Al-Waqidi, Futuh el-Sham III 7, tł. A. Abdullach, s. 195.

81 Por. Kennedy, Wielkie arabskie podboje, s. 78.

82 Por. Nicolle, Yarmuk AD 636, s. 67.
} 
rzeki Jarmuk, która jest wschodnim dopływem Jordanu, na południu od Jeziora Tyberiadzkiego ${ }^{83}$.

Bitwa nad rzeką Jarmuk okazała się wielką zbrojną konfrontacją, składającą się z krwawych i zaciekłych potyczek, które trwały w sumie sześć dni, i zakończyła się zwycięstwem Arabów 20 sierpnia 636 roku $^{84}$. Jeszcze zanim doszło do starcia zbrojnego, Vahan wysłał Jabalę jako posła do muzułmanów, aby powiedział im, że nie ma sensu walczyć, ponieważ siły Bizancjum są przeogromne i nikt spośród wrogów cesarza nie uniknie zagłady. Muzułmanie jednak nie tylko nie przestraszyli się, ale wręcz namawiali Jabalę, aby przeszedł na ich stronę, przyjmując jednocześnie islam. Jabal jednak stanowczo odmówił ${ }^{85}$. Al-Waqidi operuje tutaj znów antytezą: przeciwstawia butę chrześcijan rozwadze i odwadze muzułmanów. Z drugiej strony z treści źródła wynika jasno, że jego autor nie traktuje bitwy nad Jarmukiem jako starcia dwóch armii, którego celem jest podbój. Dla niego było to starcie wyznawców dwóch religii, które miało wykazać, czy silniejszy jest Allah czy Chrystus. Stojące naprzeciw siebie armie mogły bardzo łatwo stać się sojusznikami pod warunkiem, że chrześcijanie przejdą na islam. Takie postawienie sprawy nadaje bitwie nad Jarmukiem głębszego sensu. Zwycięstwo przypadnie tej stronie, którą wspiera Bóg. Będzie to oznaczać, że armia ta jest swego rodzaju armią wybraną, a to stanowiło rękojmię dalszych zwycięstw i trwałości dokonywanych podbojów. W konsekwencji krew przelana nad Jarmukiem będzie życiodajnym nasieniem dla następnych pokoleń wyznawców Allaha. Al-Waqidi stworzył zatem ex post fundament dla pogłębionej teozoficznie interpretacji zdarzeń historycznych. Ta właśnie interpretacja odsłania prawdziwe znaczenie wydarzeń. Metoda al-Waqidiego nie jest oczywiście żadnym novum, gdyż sięga ona początków historii historiografii grecko-rzymskiej, a swe apogeum znajduje w pismach historyków wczesnochrześcijańskich. Jednak przeniesiona na

83 Por. Hitti, Dzieje Arabów, s. 129; Kennedy, Wielkie arabskie podboje, s. 79.

84 Por. Nicolle, Yarmuk AD 636, s. 69; A. Popov, Polnaja istorija islama i arabskih zavojevanij v odnoj knige, Moskwa 2009, s. 56; J. Carr, Fighting Emperors of Byzantium, Barnsley 2015, s. 114-115; M. Hadzhson, Istorija Islama. Islamskaja cyvilizacyja ot rozhdenija do nashyh dnej, tł. A. Gordijenko, Sankt-Peterburg 2017, s. 424; J. Kulakovskij, Istorija Vizantiji, t. 2, Sankt-Peterburg 1996, s. 144.

85 Al-Waqidi, Futuh el-Sham III 9, t1. A. Abdullach, s. 197-198. Z drugiej zaś strony co innego twierdzi Steven Runciman. Por. S. Runciman, Dzieje wypraw krzyżowych, tł. J. Schwakopf, Warszawa 1987, s. 28-29. O burze piaskowej pisze również John Glubb. Por. J. Glubb, The Great Arab Conquests, Englewood Cliffs 1964, s. 178. 
grunt muzułmański zostaje ona zręcznie wprzęgnięta w islamską ideologię wojny, stanowiąc niejako dopełnienie Koranu.

Sam przebieg bitwy w relacji al-Waqidi'ego wyglądał następująco: pierwszy dzień zaczął się pojedynkiem elitarnych formacji obu wojsk. Około południa Vahan wysłał do przodu doborową piechotę bizantyńską, wspartą kilkoma oddziałami łuczników. Walka toczyła się aż do zachodu słońca ${ }^{86}$. Reakcję muzułmanów w chwili rozpoczęcia bitwy tak opisuje al-Waqidi:

Abu 'Ubaydah wykrzyknął: „Wrogowie Allaha przyszli, aby walczyć z nami. Odeprzyjcie ich atak. Bądźcie mężni i z cierpliwością i prawdą walczcie z wrogami. Zwycięstwo pochodzi od Allaha”. I zaczął się modlić tymi słowami: „O Najwyższy, wypełnij ich serca lękiem. Nam zaś daj twardość i zimną krew. O Ty, który powiedziałeś: «I trzymajcie się mocno Boga! On jest waszym Panem! Jakże to wspaniały Pan! Jakże to wspaniały Pomocnik!»" ${ }^{87}$.

Al-Waqidi jest stale wierny swej tezie. Słowa „Bóg z nami” są tego najlepszym dowodem, podobnie jak przekonanie, że „zwycięstwo pochodzi od Allaha". Jest to swego rodzaju streszczenie zawartej w Koranie ideologii świętej wojny. Tutaj natomiast stanowi prolog do opisu jednej z najważniejszych bitew w historii islamskiego oręża $\mathrm{i}$ islamskiego imperializmu.

Rankiem drugiego dnia Bizantyńczycy przejęli inicjatywę i rozciągnąwszy siły wzdłuż całego frontu, błyskawicznie zaatakowali Arabów. Ci ostatni byli zaskoczeni tym manewrem, który zbiegł się w czasie z porannym namazem ${ }^{88}$. Moment ten nie był oczywiście wybrany przypadkowo, lecz było to ze strony Bizantyńczyków klasyczne wykorzystanie chwili „religijnej” słabości wroga. Zamiary Vahana były oczywiste - chciał on opanować centrum pola walki, atakując jednocześnie oba skrzydła sił nieprzyjacielskich. W ten sposób pragnął on wykorzystać dużą przewagę liczebną wojsk cesarskich. Po trzech udanych natarciach bizantyńskich Arabowie cofnęli się, co umożliwiło oddziałom greckim zdobycie jednego $\mathrm{z}$ ich obozów ${ }^{89}$. To wydarzenie tak relacjonuje al-Waqidi:

W tym samym czasie, kiedy on [Abu 'Ubaydah] modlił się, Rzymianie zaatakowali prawe skrzydło wojska muzułmańskiego. Rzymianie napierali

\footnotetext{
${ }^{86}$ Por. Nicolle, Yarmuk AD 636, s. 69; Bolshakov, Istorija Halifata, t. 2, s. 67.

87 Al-Waqidi, Futuh el-Sham III 9, tł. A. Abdullach, s. 200.

88 Por. S. O'Shea, Sea of Faith, New York 2006, s. 39-40.

89 Por. Nicolle, Yarmuk AD 636, s. 69.
} 
niesamowicie, ale muzułmanie twardo stawili im czoła, wykazując się męstwem. Wytrzymali też natarcie drugiego oddziału Bizantyńczyków. Lecz kiedy uderzył na nich trzeci, byli zmuszeni się wycofywać. Wtedy do przodu wystąpił 'Amr ibn Madijyakrib Zubajdi, wódz plemienia Zubajd. Kiedy zobaczył swoich ludzi uciekających, wykrzyknął: „O plemię Zubajd, wy uciekacie od wroga, ponieważ boicie się wypić z kielicha śmierci! Czy wybieracie dla siebie hańbę? Czyż nie wiecie, że Bóg wspiera wiernych sobie zwycięstwem i cierpliwością. Któż może uciec od raju? Czy wolicie piekło i gniew Najwyższego?”. Kiedy Arabowie usłyszeli jego słowa, zbiegło się do niego około 500 wojowników i razem z nim poszło do kontrataku. Z kolei plemię Dausytów było z Abu Hurairą ${ }^{90}$. On to rozwinął swój sztandar, wymachiwał nim i wykrzykiwał: „O ludzie, śpieszcie się na spotkanie rajskich dziewic w pobliżu Pana Światów. Nie ma bowiem dla Allaha miejsca, które by umiłował bardziej niż to pole walki. Bóg kocha tych swych poddanych, którzy uczestniczą w bitwie”. Wtedy Dausyci poszli do ataku na Rzymian. Rozpoczęła się bitwa, która rozkręciła się jak młyński kamień ${ }^{91}$.

Autor tego opisu eksponuje wyraźnie rolę charyzmatycznych dowódców, których cechuje męstwo i bojaźń wobec Allaha. Milcząco zaś odmawia owej charyzmy oficerom cesarskim. Buduje w ten sposób napięcie literackie, które zachęca czytelnika do dalszej lektury, a jednocześnie proponuje mu ściśle określoną linię etyczno-moralną. Jednak nie mógł przemilczeć faktu, że starcie to zakończyło się porażką wojsk kalifa. Stało się to jednak pretekstem do ciekawego opisu: oto uchodzące z pola bitwy oddziały muzułmańskie napotkały arabskie kobiety, które przebywały w obozach. Te zaś zaczęły wyzywać uciekających mężczyzn i obrzucać ich kamieniami ${ }^{92}$. Ten wywód al-Waqidi'ego posiada kilka warstw znaczeniowych. Już sam obraz kobiet, które biorą inicjatywę w swoje ręce, był w społeczeństwie muzułmańskim czymś rewolucyjnym. Oficjalne, publiczne karcenie mężów zaś było wręcz nie do pomyślenia. Wykazana natomiast tym sposobem odwaga kobiet arabskich, kontrastująca ze zwie-

90 Abdurrahman ibn Sakhr ad-Dawsi al-Jamani bardziej znany jak Abu Hurairah. Żył w latach 601-676. Od momentu przejścia na islam do samej śmierci Mahometa był jego bliskim towarzyszem. Autor ponad 5 tysięcy hadysów - przekazów o życiu i działalności proroka. Pełnił urząd władcy Medyny. Był też namiestnikiem Bachrajnu. Por. A. Ali-zade, Islamskij entsyklopedicheskij slovar, Ansar 2007, s. 35.

91 Al-Waqidi, Futuh el-Sham III 48, tł. A. Abdullach, s. 244.

92 Al-Waqidi, Futuh el-Sham III 49, tł. A. Abdullach, s. 244-245. Por. Nicolle, Yarmuk $A D$ 636, s. 70. 
rzęcym przerażeniem i haniebną ucieczką ich mężów, jest dopełnieniem tego obrazu. Nie należy przy tym zapominać, że tekst ten był przeznaczony dla czytelnika muzułmańskiego płci męskiej. Al-Waqidi bardzo umiejętnie buduje narrację wizji hańby, traktując ucieczkę z pola bitwy jako najniższą formę moralnego upadku wyznawcy islamu. Jest ona tutaj ukazana wręcz jako akt apostazji.

Interwencja kobiet miała sprawić, że Arabowie przestali się cofać i zaczęli mężnie walczyć. Poskutkowało to wyhamowaniem impetu natarcia wojsk bizantyńskich. Kiedy zaś linia frontu została ustabilizowana, Khalid ibn al-Walid wysłał rezerwowe oddziały jazdy, aby wsparły najpierw prawe, a potem lewe skrzydło jego armii. W tym czasie do kontrataku przeszło również islamskie centrum, wsparte jazdą, którą dowodził Zarrar. Posunięcia te sprawiły, że muzułmanie odzyskali utracone pozycje $^{93}$. Zaistniałą sytuację tak skomentował al-Waqidi:

Michał Dausi oznajmił: „Kobiety były groźniejsze od Rzymian. Wtedy bowiem muzułmanie powrócili i z determinacją walczyli z Rzymianami. Katama ibn Aikham Kinani był na czele tego wojska i atakując armię nieprzyjaciół, złamał trzy włócznie i trzy miecze, za każdym razem wołając: «Kto pożyczy mi miecz albo kopię na drodze Allaha, jego nagroda też będzie u Allaha!». Potem zaś dodał: «O plemię Qajs, bierzcie waszą cząstkę nagrody i cierpliwości. Przecież cierpienie w tym świecie prowadzi do szczęścia w życiu wiecznym». Usłyszawszy to, jego ludzie zaczęli walczyć bardzo zażarcie"94.

Trzeciego dnia sytuacja była niemal analogiczna. Arabski dziejopis zanotował pod tą datą, że ,trzeci dzień był najgorszy. Muzułmanie trzykrotnie wycofywali się. Trzykrotnie też kobiety ratowały sytuację, zawracając mężczyzn do boju. Jednak straty w ludziach były wśród Arabów niewielkie, chociaż było wielu rannych, Rzymianie zaś ponieśli w tej walce ciężkie straty osobowe" 95 . Z powyższego tekstu wynika, że wojsko bizantyńskie podjęło trzeciego dnia podobny atak jak dnia poprzedniego, łamiąc szyk muzułmański i zmuszając wojska kalifa do odwrotu. W zaistniałej sytuacji ponownie kobiety, stosując tą samą ,taktykę”, czyli piętnując tchórzostwo uciekających mężczyzn, powstrzymały wycofujące się oddziały i zmobilizowały je do kontynuowania walki. W następstwie tych

\footnotetext{
93 Por. Nicolle, Yarmuk AD 636, s. 72.

94 Al-Waqidi, Futuh el-Sham III 51, tł. A. Abdullach, s. 247.

95 Al-Waqidi, Futuh el-Sham III 55, tł. A. Abdullach, s. 253.
} 
wydarzeń utarło się podobno wśród Arabów powiedzenie, że „łatwiej jest walczyć z Rzymianami niż przeciwstawić się własnym kobietom"96. Ostatecznie sytuację znowu uratował Khalid ibn al-Walid, wykorzystując jazdę rezerwową. Jednak tego dnia, mimo optymistycznej wersji al-Waqidi'ego, straty osobowe wśród muzułmanów były o wiele większe niż dzień wcześniej ${ }^{97}$.

Czwarty dzień walki charakteryzował się zaciekłymi starciami wrogich wojsk i zadecydował o losach całej bitwy. Vahan zdecydował się na kolejny atak, wiedział bowiem, że Arabowie stracili poprzedniego dnia większość swoich łuczników. Postanowił wykorzystać przewagę liczebną wojsk bizantyńskich. Tego dnia jednak oddziały ormiańskie pozostały bez jej wsparcia. Z kolei muzułmanie pod wodzą Abu 'Ubaydy i Jazyda przeszli do ofensywy. Ich oddziały uderzyły na centrum i prawe skrzydło wojsk bizantyńskich. Khalid ibn al-Walid z kolei wysłał połowę jazdy rezerwowej, aby wesprzeć Qajsa ibn Hubairakha ${ }^{98}$. Te taktyczne manewry islamskiego dowództwa sprawiły, że Ormianie i Arabowie wyznania chrześcijańskiego zostali zaatakowani jednocześnie z trzech stron przez oddziały Khalida ibn al-Walida, Qajsa ibn Hubairakha i Szurahbila ${ }^{99}$. Siła muzułmańskiego uderzenia była tak duża, że mimo męstwa oddziały bizantyńskie zaczęły się w końcu cofać, Ghassanidzi zaś zostali wręcz rozgromieni ${ }^{100}$. Sprzymierzeńcem muzułmanów była tego dnia burza piaskowa. Jednak w największym stopniu do przegranej Bizantyńczyków przyczyniła się taktyka, jaką obrał Vahan. To ona sprawiła, że podczas jego ataku na północną flankę obozu arabskiego jazda bizantyńska została odcięta od piechoty. Bizantyńczycy stosowali wówczas, zgodnie z zalecieniami Strategikonu Maurycjusza, formacje mieszane, których część stanowiła piechota, a część - jazda ${ }^{101}$. Kiedy jazda została odcięta od mającej ją wspierać piechoty, Arabowie uniemożliwili jej odwrót i rozgromili ją. Jednocześnie kawaleria arabska uderzyła na lewe skrzydło wojsk bizantyńskich, zmuszając oddziały

96 Al-Waqidi, Futuh el-Sham III 49, tł. A. Abdullach, s. 244-245. Por. Nicolle, Yarmuk AD 636, s. 70.

97 Por. Nicolle, Yarmuk AD 636, s. 72.

98 Jeden z dowódców wojska muzułmańskiego. Dowodził flanką wojska arabskiego. Al-Waqidi, Futuh el-Sham III 57, t1. A. Abdullach, s. 291.

99 Szurahbil ibn Hasan. Jeden z wysoko postawionych dowódców wojska arabskiego. Al-Waqidi, Futuh el-Sham III 59, t1. A. Abdullach, s. 290.

100 Por. Nicolle, Yarmuk AD 636, s. 73; Bolshakov, Istorija Halifata, t. 2, s. 67-68.

101 Por. Kaegi, Byzantium, s. 121. 
ormiańskie, którymi dowodził naczelny wódz armii cesarskiej, Vahana, do odwrotu ${ }^{102}$. Tego dnia po stronie muzułmańskiej odznaczyła się szczególnie jazda arabska pod dowództwem Zarrara, która skrycie podążała za wycofującymi się oddziałami wroga, ukrywając się za Tell al-Jumua, a następnie ścigała i wycinała jazdę bizantyńską aż do Ayn Dhakar. Ta ucieczka otworzyła Zarrarowi drogę na most przez Wadi Ruqqad, tym bardziej że jeden z jeńców imieniem Abu Juayd chętnie wskazał im drogę. W ten sposób reszta wojsk cesarskich została odcięta od głównego obozu w Jaqusah. Mogła jedynie wycofać się bądź w dolinę Jarmuku, bądź na wzgórza Ruqqad, bądź też starać się przerwać pierścień okrążenia $^{103}$. W tym czasie centrum i lewe skrzydło wojsk kalifa ponosiły dotkliwe straty z rąk bizantyńskich łuczników. Ten dzień wejdzie do historii wojskowości muzułmańskiej jako „Dzień utraconych oczu”"104. Niemając wsparcia ze strony własnej kawalerii, wojska kalifa nie były w stanie przeciwstawiać się konnym łucznikom bizantyjskim, którzy zadawali im ciężkie straty. Aby zapobiec katastrofie, Abu 'Ubaydah wraz z Jazydem uderzyli na tyły oddziałów cesarskich. W czasie tego manewru jeden z oddziałów islamskich, znajdujący się na lewo od wojsk Abu 'Ubaydy, którym dowodził Iqram ibn Abi Jahla, został odcięty od sił głównych. Wszyscy wojownicy zginęli lub zostali ciężko ranni ${ }^{105}$. Tak opisuje to wydarzenie al-Waqidi:

Vahan był bardzo rozgniewany z powodu śmierci dwóch wodzów armii chrześcijańskiej. Zawołał więc donośnym głosem: „Dwóch spośród naszych wodzów zabito w jednym dniu. Nie sądzę, żeby Chrystus nas wspierał". Potem zaś rozkazał łucznikom wypuścić tysiące strzał jednocześnie. I wypuszczono w prawowiernych około 100 tysięcy strzał. Około 700 wojów straciło też tego dnia oko. Dlatego ten dzień nazwano „Dniem utraty jednego oka”. Gdy Vahan spostrzegł, że atak łuczników przyniósł [pozytywny] skutek, rozkazał piechocie iść do natarcia. Rzymianie poszli więc do boju. Muzułmanie zaś, mając wiele rannych, zaczęli się wycofywać ${ }^{106}$.

102 Por. Nicolle, Yarmuk AD 636, s. 73-74; Bolshakov, Istorija Halifata, t. 2, s. 67-68.

103 Por. Nicolle, Yarmuk AD 636, s. 73-76.

104 Tak nazwano czwarty dzień walki nad Jarmukiem, ponieważ wielu spośród Arabów utraciło oko w tym dniu z powodu ostrzału konnych łuczników bizantyńskich. O tym wydarzeniu wspomina także kitab al-Baladhuri. Por. Al-Baladhuri, The Origins of the Islamic State X 136, t. 1, ed. Ph. Hitti, New York 1916, s. 208.

105 Por. Nicolle, Yarmuk AD 636, s. 73-77.

106 Al-Waqidi, Futuh el-Sham III 59, tł. A. Abdullach, s. 260. 
W czwartym dniu bitwy miało również miejsce wydarzenie, które przeszło do historii. Za bron chwyciły wówczas kobiety pod dowództwem siostry Zarrara - Khawly bint al-Azwar. Z kolei żona Abu Sufyana, Hint bint 'Utbah, nawoływała Arabów, aby wyrżnąć w pień nieprzyjaciela ${ }^{107}$. Pod naciskiem wojowników kalifatu szyk bizantyński został złamany, a żołnierze cesarza poszli w rozsypkę. Muzułmanie ruszyły za nimi w pościg. W tej walce siostra Zarrara, Khawlah bint al-Azwar, została ranna. Zniesiono ją z pola bitwy z raną ciętą, zadaną mieczem. Tekst źródła tak opisuje te zmagania:

Abdullach ibn Kurt przekazuje: „Byłem świadkiem wielu bitew, ale nigdy nie widziałem niczego gorszego od owego dnia utraty jednego oka”. Nigdy przedtem nie widziałem, aby kobiety Kurajszytów ${ }^{108}$ tak walczyły, jak nad Jarmukiem. Kiedy Rzymianie nacierali, kobiety wyszły na pole walki z mieczami. Walczyły zaciekle, wykazując ogromne męczeństwo. One też zawracały uciekających muzułmanów, bijąc ich konie kijami po pyskach. Jedne spośród nich walczyły z przeciwnikami, inne powstrzymywały uciekających mężczyzn, a jeszcze inne opatrywały rannych. Gdy Rzymianie zaatakowali je, wówczas niewiasty z plemion Lakhm, Juzam i Khawlan zaczęły uciekać. Wtedy Khawlah bint al-Azwar, Umm Hakim bint Kharis oraz Salama bint Luai zaczęły bić je po twarzach i głowach krzycząc: „Uciekajcie! Wasza obecność tylko osłabia nasze szeregi!". W odpowiedzi na to uciekinierki powróciły do szeregów, gotowe walczyć na śmierć i życie. Chwała Najwyższemu za to, jak kurajszyckie kobiety walczyły nad Jarmukiem!109

Opis tego ważnego epizodu z bitwy nad Jarmukiem nie jest przypadkowy. W patriarchalnym społeczeństwie muzułmańskim jest to ewenement. Kronikarz, pokazując moc Allaha, ukazuje jednocześnie, że charyzma męstwa została wówczas udzielona nie tylko mężczyznom, lecz również kobietom. Zwycięstwo to jest zatem wspólnym dziełem wyznawców islamu jako takich. Fakt wspólnej walki mężczyzn i kobiet podkreśla też ich wspólne wybraństwo. Po stronie bizantyńskiej walczą tylko żołnierze cesarza, po stronie kalifatu walczy całe społeczeństwo. Ziemia zdobyta w ten sposób nie jest więc tylko podbitym terytorium, lecz jest ona ziemią, którą

107 O Hint bint Utbie wspomina także kitab al-Baladhuri. Por. Al-Baladhuri, The Origins of the Islamic State X 135, ed. Ph. Hitti, s. 207.

108 Kurajszyci - plemię arabskie zamieszkujące Mekkę. Mahomet wywodził się właśnie z tego plemienia.

109 Al-Waqidi, Futuh el-Sham III 60, t1. A. Abdullach, s. 261. 
islam posiadł wspólnym wysiłkiem mężczyzn i kobiet. Innymi słowy owoc tej świętej wojny jest prawdziwym „dobrem wspólnym”, do którego wszyscy mają prawo. Inaczej mówiąc, wojna święta to wojna totalna. Al-Waqidi przedstawia to, posługując się umiejętnie gradacją napięcia. Jednocześnie jego opis jest jasny i prosty, a zatem zrozumiały dla nawet niewyrobionego czytelnika czy słuchacza.

Piątego dnia bitwy Vahan podjął ostatnią próbę ocalenia swojego wojska, ale bez skutku. Ostatecznie Bizantyńczycy znaleźli się w pułapce między Wadi Ruqqad a wąwozem Jarmuk, zupełnie odcięci od swojego obozu w Jaqusah. Armia kalifatu zaś zdołała opanować przestrzeń między Wadi Allan a Wadi Ruqqad. Nie atakując siebie nawzajem, prawdopodobnie $\mathrm{z}$ powodu wyczerpania walkami toczonymi $\mathrm{w}$ dniach poprzednich, zarówno Khalid ibn al-Walid, jak i Vahan zebrali resztki swej jazdy, aby z ocalałych kawalerzystów sformować nowe oddziały ${ }^{110}$. Wtedy też wojska kalifa zaatakowały bizantyński obóz w Jaqusah. Zgodnie z tradycją to wydarzenie miało mieć miejsce w nocy. Prawdopodobnie Zarrar, zachęcony łatwym zdobyciem mostu ${ }^{111}$, zapragnął również zdobyć obóz, który znajdował się w odległości około osiemnastu kilometrów od mostu. Kiedy Zarrar tam dotarł, zauważył, że jego obrona była bardzo słaba. Część obrońców obozu ratowała się ucieczką wzdłuż wspomnianej już rzymskiej drogi, reszta zaś została niejako uwięziona nad stromym zboczem Wadi Ruqqad i wąwozu Jarmuk ${ }^{112}$.

Szósty i ostatni dzień walk rozpoczął się od potyczki między formacjami Gargisa aAbu 'Ubaydy, podczas której Gargis zostałzabity. Po tym pomyślnym prologu także i reszta wojsk muzułmańskich uderzyła na wroga. Najbardziej zacięte walki rozgorzały na północno-wschodnim skrzydle Bizantyńczyków, gdzie oddziały Gargisa połączyły się z oddziałami piechoty bizantyńskiej pod powództwem Vahana. Tradycja, która mówi o burzy piaskowej szkodzącej Bizantyńczykom, jest słabo udokumentowana. Można uważać ją za mit, ponieważ informacja o niej pochodzi ze źródeł późniejszych, a mianowicie od Theophanesa, który próbował w ten sposób wytłumaczyć klęskę wojsk chrześcijańskich, czterokrotnie górujących liczebnie nad przeciwnikiem. Theophanes obarczył winą za porażkę nie tylko ową burzę piaskową, lecz generalnie niepogodę oraz pustynny teren, który był niejako naturalnym środowiskiem Arabów ${ }^{113}$. Pomijając dywagacje na temat warunków atmosfe-

110 Por. Bolshakov, Istorija Halifata, t. 2, s. 68-69.

111 Lokalizacja mostu. Por. Kaegi, Byzantium, s. 121.

112 Por. Nicolle, Yarmuk AD 636, s. 77; Bolshakov, Istorija Halifata, t. 2, s. 69.

113 Feofan Ispovednik, Hronografia, 1.m. 6126, r.ch. 626, tł. V.I. Obolenskij, Moskwa 1987, s. 159. 
rycznych, należy podkreślić, że w pewnym momencie wśród Bizantyjczyków wybuchła panika. Stało się to wówczas, gdy uświadomili oni sobie, że zostali okrążeni. Wtedy niektórzy z nich złożyli broń i poddali się. Nie były to jednak zbyt liczne przypadki, zwłaszcza że Arabowie nie chcieli brać dużej ilości jeńców. Inni żołnierze cesarza próbowali salwować się ucieczką po stromych zboczach i klifach, co wielu z nich przypłaciło życiem. Jednocześnie ucieczka ta okryła ich piętnem hańby ${ }^{114}$.

Po ustaniu działań wojennych także i muzułmanie zaczęli liczyć swoje straty. W bitwie tej zginęło lub też odniosło rany wielu wybitnych dowódców kalifa. I tak Abu Sufyan, mąż budzącej wśród wrogów postrach Hind bint Utby, był pomiędzy rannymi w walkach z bizantyńskimi łucznikami. Z kolei Amir ibn Abi Waqqas ${ }^{115}$, który dowodził siłami arabskimi przed ustanowieniem Khalida ibn al-Walida głównodowodzącym, został zabity podobnie jak i wielu innych, wysokich rangą dowódców. Trzeba przy tym zaznaczyć, że muzułmanie ponieśli o wiele mniejsze straty niż armia bizantyńska, zginęło bowiem ok. 3 tysięcy ludzi kalifa, podczas gdy wojska cesarskie straciły ok. 50 tysięcy żołnierzy. Ponadto tysiące Bizantyńczyków uciekło do Emesy i Egiptu ${ }^{116}$. Al-Waqidi tymczasem podaje, że muzułmanie utracili 4 tysiące ludzi, liczbę zabitych Bizantyńczyków natomiast powiększa dwukrotnie:

Amir ibn Yasir przekazał za Naufalem ibn Adim, któremu przekazał to Jabir ibn Nasra, który z kolei usłyszał od Khamida ibn Majida: „Abu 'Ubaydah próbował policzyć [trupy] Rzymian, ale ich liczba nie dawała się ustalić. Doliczono się 105 tysięcy zabitych Rzymian. Muzułmanie zaś stracili 4 tysięcy ludzi. Muzułmanie skierowali się [następnie] w góry i doliny, aby wyłapać resztki wojsk rzymskich. [Wtedy] spotkali pasterza, który powiedział, że tamtędy przechodziło wojsko w liczbie około 40 tysięcy z patrycjuszem na czele. Nie mógł to być nikt inny, jak tylko Vahan. Khalid ibn al-Walid wziął elitarne oddziały jazdy i rzucił się w pościg za Vahānem. Doścignął go pod Damaszkiem. Muzułmanie atakowali z okrzykiem: „Allahu Akbar!”. W tym boju Vahān został zabity. Zabił go Asim ibn Khawwal Yarbui ${ }^{117}$.

Analizowane tutaj źródło przytacza również list, który Abu 'Ubaydah, przybywszy do Damaszku po zakończeniu bitwy, miał napisać do kalifa Omara. Oto jego treść in extenso:

114 Por. Nicolle, Yarmuk AD 636, s. 80; Bolshakov, Istorija Halifata, t. 2, s. 69-70.

115 Bolshakov, Istorija Halifata, t. 2, s. 70-71.

116 Por. Nicolle, Yarmuk AD 636, s. 81-82.

117 Al-Waqidi, Futuh el-Sham III 67, tł. A. Abdullach, s. 271-272. 
W imię Allaha Wszechmogącego i Miłosiernego i niech będzie Jego błogosławieństwo nad Wybranym Prorokiem i Posłańcem. Od Abu 'Ubaydy 'Amira ibn al-Jaraha [...]. Wiedz, o Panie Prawowiernych, że ja przybyłem nad Jarmuk, a Vahan dowodzący wojskiem Rzymian rozbił obóz naprzeciw nam. Muzułmanie nigdy nie widzieli większego wojska. Ale Allah zmniejszył ich liczbę i wspierał nas dzięki Swojej szczególnej łasce. My zabiliśmy 105 tysięcy spośród nich i wzięliśmy do niewoli 40 tysięcy, Allah zaś darował szachadę 4 tysiącom prawowiernych [...]. Așim ibn Khawwal zabił Vahana pod Damaszkiem. Przed finalnym pojedynkiem, jeden z Rzymian, Abu Jayd z Himsu, oszukał ich i rzucił wielu spośród nich w wodę, gdzie potonęli [...]. Pokój, miłość Allaha i Jego błogosławieństwo Tobie i wszystkim muzułmanom! $!^{118}$

Oba teksty podają liczbę zabitych z obu stron, przy czym stosunek 105 do 4 oznacza, że straty bizantyńskie były ponad 26 razy większe niż straty muzułmańskie. Proporcje te należy prawdopodobnie uznać za liczby symboliczne z zakresu gematrii ${ }^{119}$. Do tego należy dodać 40 tysięcy wziętych do niewoli żołnierzy bizantyńskich, aby statystycznie dopełnić ogromu katastrofy nad Jarmuk. Z kolei dla większego uwiarygodnienia tego przekazu al-Waqidi podaje na wstępie czteropokoleniowy (on stanowi w nim piąte pokolenie) ciąg tradycji islamskiej, który o tym mówił. Tradycja ta była tak dokładna, że wspominała także imię tego, kto zabił bizantyńskiego naczelnego wodza, Vahana ${ }^{120}$. Różnie też potoczyły się losy innych dowódców cesarskiej armii. Teodor zginął w walce ${ }^{121}$, Niketas zaś dotarł do Emesy, gdzie chciał prowadzić rokowania z kalifem, ale jego propozycja została odrzucona. Jabal natomiast uciekł z pola bitwy i w ten sposób ocalił (przynajmniej) życie ${ }^{122}$.

\section{Wnioski końcowe}

Obraz bitwy nad Jarmuk pióra al-Waqidi'ego jest dobrą ilustracją teokratycznej interpretacji wojny. Jest to wojna święta, prowadzona przeciw

118 Al-Waqidi, Futuh el-Sham III 67, tł. A. Abdullach, s. 272.

119 Gematria - system numerologii, który opiera się na języku i alfabecie hebrajskim.

120 Al-Waqidi, Futuh el-Sham III 67, tł. A. Abdullach, s. 309.

121 Por. Z. Ryniewicz, Leksykon bitew świata, Warszawa 2004, s. 201; McAllister, The sword and shield of God, s. 39.

122 Por. Nicolle, Yarmuk AD 636, s. 81. 
największej ówczesnej potędze niewiernych - Bizancjum. Za obu armiami stoją ich boscy protektorzy: Allah i Chrystus. Nad każdą z armii powiewają sztandary, a na nich widnieją symbole wiary. Bitwa trwa sześć dni, jak biblijne dzieło stworzenia świata. To właśnie w czasie tego „heksameronu” rodzi się nowy kształt Śródziemnomorza. Stary porządek upada, czy raczej tonie w strumieniach krwi 105 tys. poległych żołnierzy cesarza. Do tego należy dodać wspomnianych wyżej 40 tys. jeńców. Straty zwycięzców to 4 tys. zabitych. Al-Waqidi, bazując na długiej tradycji muzułmańskiej dotyczącej bitwy nad Jarmukiem, dał jasną i instruktywną interpretację tego wydarzenia. Interpretacja ta miała charakter przesiąkniętej duchem koranicznej parenezy wykładni istoty świętej wojny. Ukazuje muzułmanów jako naród wybrany. Godność tę otrzymują na polu bitwy zarówno mężczyźni, jak i kobiety. Zdobycze terytorialne nie są w tym kontekście dziełem przypadku, lecz są one darem Allaha, wynikiem jego woli. Człowiek jest tylko narzędziem w jego ręku. Bóg chrześcijan nie wsparł na tyle zastępów swych wyznawców, aby nie uległy one czcicielom Allaha. Bitwa ta przesądziła nie tylko o zmianie sytuacji geopolitycznej, ona ukierunkowała również historiografię i historiozofię obu mocarstw w następnych stuleciach.

\title{
Kitab Futuh el-Sham of (Pseudo-) Muhammad ibn Umar al-Waqidi as a Source for Studying the Battle on the Yarmuk River (636)
}

\author{
(summary)
}

This article focuses on the course of the Battle of Yarmouk, which took place on August 20, 636 between the Byzantine army under the command of Vahana and the caliphate forces commanded by Khalid ibn al-Walid. The source of these analyzes is kitab, whose author is from (Pseudo-) al-Waqidi. It is not about analyzing the purely military aspect of this clash, but about its interpretation in Islamic tradition at the beginning of the $9^{\text {th }}$ century. One of the bearers of this tradition is al-Waqidi. The clash over Yarmouk was not only a military defeat of the Byzantine Empire, but a defeat that determined the fate of Syria and Palestine. They came under the rule of the caliphate and never returned to the Empire. Interpreting this event, al-Waqidi emphasizes that it was a breakthrough in creating a new order in this part of the world. Moreover, this new order was created thanks to the bravery of Muslim warriors and their wives. Emphasizing the role of women in this victory is particularly noteworthy because Islam usually does not highlight their significance. AlWaqidi also points to the fact that in the battle of Yarmouk, the Christian God did not effectively support his followers. Allah did so, which resulted in defeat of the imperial army. The fight over Yarmouk was, therefore, in al-Waqidi's opinion on two levels: human and supernatural. Allah's followers won a victory in it, which was not only a victory over Christians, but also over the faith. In this sense, the work analyzed here is an important 
witness to the emergence of an imperial Muslim tradition that combines historical and religious interpretation.

Keywords: Jarmuk; (Pseudo-) al-Waqidi; Vahan; emperor Heraclios; calif 'Umar ibn al-Khattab (Omar); Khalid ibn al-Walid; Palestine; Syria

\section{Kitab Futah el-Sham (Pseudo-) Muhammada ibn Umar al-Waqidi'ego jako źródło do studium bitwy nad rzeką Jarmuk (636)}

(streszczenie)

Artykuł przedstawia przebieg bitwy nad rzeką Jarmuk, do której doszło 20 sierpnia 636 roku pomiędzy wojskami bizantyńskimi pod dowództwem Vahana i siłami kalifatu, którymi dowodził Khalid ibn al-Walid. Podstawę źródłową niniejszych analiz stanowi kitab, którego autorem jest z (Pseudo-) al-Waqidi. Nie chodzi o analizę czysto wojskowego aspektu tego starcia, lecz o jego interpretację $\mathrm{w}$ tradycji islamskiej na początku IX wieku. Jednym z nosicieli tej tradycji jest właśnie al-Waqidi. Starcie nad Jarmukiem było nie tylko klęską militarną Cesarstwa Bizantyńskiego, lecz przegraną która przesądziła o dalszych losach Syrii i Palestyny. Przeszły one bowiem pod panowanie kalifatu i już nigdy nie powróciły do cesarstwa. Al-Waqidi, interpretując to wydarzenie, podkreśla, że był to przełom w tworzeniu nowego porządku w tej części świata. Co więcej, ów nowy ład powstał dzięki męstwu muzułmańskich wojowników i ich żon. Podkreślenie roli kobiet w tym zwycięstwie jest szczególnie godne uwagi, ponieważ w islamie nie eksponuje się zwykle ich znaczenia. Al-Waqidi podkreśla również, że w bitwie nad Jarmukiem Bóg chrześcijan nie wsparł skutecznie swych wyznawców. Uczynił to natomiast Allah, czego efektem była klęska wojsk cesarskich. Walka nad Jarmukiem toczyła się więc zdaniem al-Waqidi' ego na dwóch płaszczyznach: ludzkiej i nadprzyrodzonej. Wyznawcy Allaha odnieśli w niej zwycięstwo, które było nie tylko zwycięstwem nad chrześcijanami, lecz także nad ich wiarą. W tym sensie analizowane tutaj dzieło jest ważnym świadkiem powstania imperialnej tradycji muzułmańskiej, która łączy w sobie interpretację historyczną i religijną.

Słowa kluczowe: Jarmuk; (Pseudo-) al-Waqidi; Vahan; cesarz Herakliusz; kalif 'Umar ibn al-Khattab (Omar); Khalid ibn al-Walid; Palestyna; Syria

\section{Bibliografia}

\section{Źródła}

Al-Baladhuri, The Origins of the Islamic State, t. 1, ed. Ph. Hitti, New York 1916.

Al-Basri, Futuh ash-Sham, ed. W.N. Lees, Calcutta 1853-1854.

Al-Dhahbi, Mizan al-I'tidal fi Naqd al-Rijal, t. 3, Hyderabad 1953.

Al-Waqidi, The Conquest of Syria commonly ascribed to Muhammad al-Waqidi, t. 1, ed. W. Nassau Lees, Calcutta 1854.

Doctrina Iacobi nuper baptizati, tł. V. Deroche, Paris 1991. 
Ibn Hajr al-'Asqalani, Tahdhib al-Tahdhib, t. 9, Hyderabad 1967.

Imam Al-Waqidi, Futuh el-Sham, tł. A. Abdullach, Moskwa 2010.

Koran, tł. i kom. J. Bielawski, Warszawa 1986.

Feofan Ispovednik, Hronografia, tł. V.I. Obolenskij, Moskva 1976.

\section{Opracowania}

Akram A., Rytsar pustyni. Khalid ibn al-Walid. Krušenije imperij, Sankt-Petersburg 2009.

Belaev E., Sovetskaja istoricheskaya enciklopedia, red. E. Zhukov, Moskwa 1962.

Bolshakov O., Istorija Halifata, t. 2, Moskwa 1989.

Bolshakov Rozhdenije $i$ razvitije islama $i$ musulmanskoj imperiji (VII-VIII ww.), Sankt-Petersburg 2016.

Carr J., Fighting Emperors of Byzantium, Barnsley 2015.

Cecota B., Arabskie oblężenia Konstantynopola w VII-VIII wieku. Rzeczywistość i mit, Byzantina Lodziensia 21, Łódź 2015.

Cook M., Muhammad, New York 1983.

Crone P., Meccan Trade and the Rise of Islam, Princeton 1987.

Danyluk D., Prychyny uspishnyh arabskyh zavojuvan v 30-h rokah VII st. u vizantijskomu napriami: istoriohrafija pytannia, w: Aktualni problem vitchyznianoji ta vsesvitnioji istoriji, vyp. 19, Kharkiv 2016.

Dictionary of Islam, ed. T.P. Hughes, New-Delhi 1978.

Sourdel D. - Sourdel J., Dictionnaire historique de l'islam, Paris 1996.

Duri A.A., The Rise of Historical Writing among the Arabs, ed. I.I. Conrad, Princeton 1983.

Dziekan M., Symbolika arabsko-muzulmańska, Warszawa 1997.

The Encyclopaedia of Islam, t. 11, Leiden 2002.

Faizer R.S., The Issue of Authenticity Regarding the Traditions of al-Wāqidī as established in his Kitāb al-Maghāzi, ,Journal of Near Eastern Studies” 58/2 (1999) s. 97-106.

Glubb J., The Great Arab Conquests, Englewood Cliffs 1964.

Gregory T., Historia Bizancjum, tł. J. Hunia, Kraków 2008.

Gibb H.A.R. - Kramers J.H., Shorter Encyklopaedia of Islam, Leiden 1995.

Hadzhson M., Istorija Islama. Islamskaja civilizacija ot rozhdenija do nashyh dnej, tł. A. Gordijenko, Sankt-Peterburg 2017.

Hitti Ph., Dzieje Arabów, tł. W. Dembski, Warszawa 1969.

Hudari M., Zhyzneopisanije pravednyh Halifov, Moskva 2009.

Kaegi W., Byzantium and the Early Islamic Conquests, Cambridge 2005.

Kennedy H., Wielkie arabskie podboje. Jak ekspansja islamu zmieniła świat, tł. M. Wilk, Warszawa 2011.

Kukhareva E., Simvolika cveta w etnicheskoj kartine mira arabov, Moskwa 2019.

Kulakovskij J., Istorija Vizantiji, t. 2, Sankt-Peterburg 1996.

Lecker M., The Death of the Prophet Muhammad's Father: Did Wāqid̄̄ Invent Some of the Evidence?, ,Zeitschrift der Deutschen Morgenländischen Gesellschaft” 145 (1995) s. 9-27. 
McAllister S., The sword and shield of God: Byzantine strategy and tactics under Heraclius during the last Persian war and first Arab war, Stillwater 2005.

Nassau Lees W., The Conquest of Syria commonly ascribed to Muhammad al-Wāqidī, t. 1, Calcutta 1854.

Nicolle D., Yarmuk AD 636. The Muslim conquest of Syria, Peterborough 2006.

Oman C., Thestory of the Byzantine Empire, New York 1892.

O’Shea S., Sea of Faith, New York 2006.

Ostrogskij G, Istorija Vizantii, Moskwa 2011.

Popov A., Polnaja istorija islama i arabskih zavojevanij v odnoj knige, Moskwa 2009.

Rosenthal F., A History of Muslim Historiography, Leiden 1968.

Runciman S., Dzieje wypraw krzyżowych, tł. J. Schwakopf, Warszawa 1987.

Ryniewicz Z., Leksykon bitew świata, Warszawa 2004.

Sawa R., Sergiusz I, Sergios, EK XVIII 45.

Sezgin F., Geschichte des arabischen Schrifttums, t. 1, Veröffentlichungen des Instituts für Geschichte der Arabisch-Islamischen Wissenschaften 10, Leiden 1967.

Treagold W., A History of the Byzantine State and Society, Stanford 1997.

Treagold W., Bizancjum i jego armia 284-1081, tł. M. Grabska-Ryńska, Wodzisław Śląski 2011.

Zaman S., Yarmouk - The Necessity of Studying the Battle in Early Medieval Military Historiography, ,Journal of Military and Strategic Studies” 16/2 (2015) s. 160-178. 